9. Чубинський, П. П. Мудрість віків: народознавство у творчій спадщині П. Чубинського. Кн. 2 / П. П. Чубинський. - К. : Мистецтво, 1995. - 222 с.

10. Чубинский, П. Труды этнографическо-статистической экспедиции в ЗападноРусский край / П. Чубинский. - Т. I-VII. - СПб, 1872-1878.

Стаття надійшла 20.02.2016 року

УДК 821.161 .2

Оксана Денисюк

(Умань, Україна)

\title{
ОБРАЗ КОБЗАРЯ В РОМАНІ «ЗВИЧАЙНИК» Л. МУСІХІНОЇ: ТРАДИЦІЯ ТА ЛІТЕРАТУРНЕ БАЧЕННЯ
}

У статті проаналізовано роман Лілії Мусіхіної «Звичайник», який віднесено до так званий «старосвітських романів». Автор статті проводить паралелі між етнографічними матеріалами, зібраними дослідниками XVIII - початку XX ст., $i$ баченням письменницею образу кобзаря Мартина та його поводиря - Устимку.

Ключові слова: кобзар, поводир, сакральність, бідність, мобільність, сліпота, зв'язок з культом померлих, сила молитви.

Денисюк О. Образ кобзаря в романе «Звичайник» Лилии Мусихиной: традиция и литературное видение.

В статье проанализирован роман «Звичайник» Лилии Мусихиной, который относится к так называемым «старосветским романам». Автор статьи проводит параллели между этнографическими материалами, собранными исследователями XVIII - начала XX в., и видением писательницей образа кобзаря Мартына и его поводыря - Устима.

Ключевые слова: кобзарь, поводырь, сакральность, бедность, мобильность, слепота, связь с культом мертвых, сила молитвы.

Denysyuk O. The image of kobzar in novel «Zvychainyk» by Liliia Musikhina: traditions and literary vision.

The author of the article analyzed the novel «Zvychainyk»by Lyliia Musikhina. That novel was referred to the so-called «secular old-novels». The researcher draws parallels between ethnographic materials collected in the XVIII - beginning of the XX century and vision of the writer of image kobzar Martyn and his eyed boy-Ustym.

Image of kobzar could be seen in the dynamics of its development from simple blind old man to God. At the same time the image of boy Ustymis analyzed. He is «difficult» child, with talent to perform the music, the child who cans «sees by heart».

Keywords: kobzar, eyed boy, sacredness, poverty, mobility, blindness, connection with the cult of dead, the power of pray.

У сучасну культуру повертається мистецтво кобзарів та лірників. Дедалі більше уваги наших сучасників привертає це давнє й унікальне 
явище українського музичного мистецтва. Не залишила його поза увагою письменниця та етнограф Лілія Мусіхіна.

У нашій статті спробуємо порівняти етнографічні відомості, збережені в записах і дослідженнях XVIII - початку XX ст., та художнє бачення образу кобзаря письменницею.

Головними героями твору «Звичайник» $\epsilon$ дві незвичайні людини кобзар Мартин та його поводир Устимко. Мартин, 3 одного боку, звичайний старий і сліпий дід (та й не такий він уже дід - «мав заледве п’ятдесят»), а з іншого - чаклун, волхв, священик, володар душ. Устимко - звичайний хлопчина, коли слухняний, коли непосидючий, а 3 іншого боку - дитина, яка бачить духовним зором те, чого не бачить ніхто, надзвичайний співак, добрий i відважний. Їхня надзвичайність проявляється 3 перших рядків твору. Зупинимося на цих образах докладніше відповідно до визначених К. Михайловою основних ознак кобзарів: сакральність, бідність, мобільність, сліпота, зв’язок із культом померлих, сила молитви. Проте дещо змінимо порядок розташування ознак, оскільки однією 3 основних, можна 3 упевненістю сказати, обов’ язковою, у кобзарській традиції була сліпота співака.

К. Михайлова в дослідженні «О семантике странствующего певцанищего в славянской культуре» наводить думку В. Залмена про те, що в середньовіччі в деяких країнах, i не тільки європейських, одним 3 основних джерел заробітку для сліпих було мандрування зі співом. Сама ж сліпота сприймалася як заклик до занять співами [4, с. 143]. Відомі випадки, коли кобзарі самі осліпляли свою дитину (сина), щоб та продовжувала сімейну традицію. Так, у Болгарії на початку XX ст. матижебрачка іноді навмисне осліпляла одного із своїх синів для продажу сліпим жебракам, щоб згодом він годував сім’ю [4, с. 143].

К. Бюрклен, досліджуючи психічний стан сліпих, довів, що «у них розвиваються такі здібності, які зазвичай у зрячого відсутні» [1, с. 9]. «Втрата зору з самого початку підвищує значення всі інших чуттів. На перше місце виходить у сліпого слух» [1, с. 20]. Учений дійшов висновку, що, перебуваючи тривалий час у світі звуків (у більшості випадків все життя), сліпі надзвичайно добре оволодівають здатністю відчувати зв'язок між звуком голосу i характеру. За допомогою мови i слуху вони обумовлюють внутрішній зв'язок між людьми [1, с. 21], навчаються читати в людських серцях [1, с. 74]. Після низки різноманітних експериментів автор дійшов висновку, що «сліпий краще читає у наших серцях, ніж якби він бачив наші обличчя» [1, с. 76].

Надзвичайну чутливість, інтуїцію i надприродні здібності сліпих співаків відзначають чимало дослідників і самих кобзарів. За свідченням кобзаря А. Парфиненка, люди аж до початку ХХ ст. віддавали перевагу 
незрячим віщунам та ворожкам. Можемо сказати таке i про середину ХХ ст., пригадаймо популярність сліпої Ванги.

Це пов’язано з тим, що зазвичай сліпота пов’язувалася зі смертю, тому в народі вважали, що сліпі живуть одразу у двох світах - світі живих та в потойбічному. Тому вони могли бачити майбутнє, спілкуватися 3 божествами, підказувати, як уберегтися від небезпеки, як вилікувати ту чи іншу хворобу. Тут простежується тісний зв'язок сліпих музикантів 3 культом предків, яких 3 давніх часів був поширених у слов'янських народів. Адже за віруваннями українців, померлий предок, як $\mathrm{i}$ найстарший роду, може просити в божеств заступництво, померлий 3 «того» світу допомагає своїм живим нащадкам, виступає посередником (парламентером) між людьми i Богом. А сила молитва сліпця має надзвичайну силу (про це буде сказано далі).

Загалом сліпота нерідко була ознакою старості та символом мудрості в поєднанні 3 літнім віком. Одночасно нагадаймо, що існують численні приклади сліпих пророків, тобто закриті очі (які не бачать фізичний світ) $є$ обов’ язковою умовою, щоб відчувати світ божественний.

У романі Л. Мусіхіної також значну увагу приділено сліпоті головного героя. Власне, 3 цієї його якості розпочинається опис зовнішності і характеру: Дід Мартин, так звали стария, був ... темним на очі був з пелюшок. Подейкували, щуо осліпив його рідний батько, аби міг син жити іншим, таємним життям сліпих, аби не бачив неправди $і$ горя людського, а щее для того, аби було кому передати старосвітську сліпеньку мудрість, яку вони так ретельно приховують від зрячих [6, c. 31]. При цьому авторка підкреслює, що «дід Мартин ніби й не зовсім був дідом, радше - старцем» [6, с. 31].

Цікавим є сюжет, де Мартин насилає сліпоту на зрячого поводиря Сашка, який, щоб в таємниці від свого діда заробити грошей, робив вигляд ніби він сліпий: На подвір'ї за другою хатою справді стояв на колінах Сашко, простягав по-жебрацькому руку, поряд лежала дідова старизівька бікота. Очі він закотив так, щзо здавалися вони зовсім сліпими. Його обступили тітки, шморгали носами і иукали, щуо б то дати бідненькому калічці. Бо ж воно, нещзасне, саме заробити не може.

- Сашко.

- Дід Мартин розвернувся і иирокими кроками попрямував геть. Але, подумавши, обернувся у Сашкову сторону, щзось промепотів $i$ сплюнув. Зараз дід зробився таким самим страшним, як тоді, у ту буремну ніч.

Аж до межового хреста на виході з села дід Мартин ішов сердито $i$ так швидко, щзо Устимко заледве встигав за ним. Раптом мирний передвечірній сільський гомін із мішанини ревіння корів, квактання курей, 
дитячого сміху, дівочого співу та свистіння кіс десь на косовиці прорізав пронизливий крик.

- Що цุе?

- Піили. Хай трохи спробує, як воно ... [6, с. 178].

У цьому невеличкому уривку скрито надзвичайно глибокий зміст. Мартин карає хлопця не тільки за те, що той обманює людей, діда-сліпця, у якого працює поводирем, викликає жалість i сльозі «i без того жалісливих тіток» [6, с. 177]. Хлопчик вирішив перебрати на себе повноваження, права і обов'язки, які ще не заслужив (не пройшов навчання, не отримав визвілку ${ }^{*}$ ), до яких не доріс духовно (імовірно це одна з головних причин покарання). Важливо, що хлопчик розкаявся i навіть віддав зароблені крадькома (фактично украдені ${ }^{* *}$ ) гроші «якомусь сліпому, щуо не зміг у ходку піти. Скажете, щуо цуе я для нього напросив» [6, с. 193].

Повага до незрячих співаків була великою: у кожнім селі святою справою вважали їх на ніч прийняти $i$ нагодувати [6, с. 169]. Це пов'язувалося передусім із вірою в те, що інколи Господь під виглядом старця мандрує по світу: ... вірили, щзо й Бог у изі дні десь світами разом із Петром та Павлом мандрує, тож свята справа - їх нагодувати. А Бог він же такий, він хитрий. Він же не прийде і не скаже прямо, хто він, а сховається серед жебраків, сліпців, серед найпослідженіших. Через те й поважають їх так люди і так шанують ... хіба знаєи, хто перед тобою? [6, c. 213].

Пояснення поважливого ставлення до людей авторка вкладає у вуста кобзаря: Вони (люди - О. Д.), може, нас і не люблять. Але шанують нашу з тобою роботу, бо ж добре діло робимо, святі слова їм переказуємо ... повідають, часом межі стариів сам Господь, - дід перехрестився, - зо святими апостолами Павлом і Петром ходить, дивиться, чи по-Божсому люди живуть, чи ніхто нікого не кривдить, чи немає так, щуоб хтось дуже забагатів та про людей забув ... [6, с. 42].

У творі Л. Мусіхіної кобзарю і його поводирю не відмовляють у ночівлі навіть у хаті, де народжувала жінка [6, с. 62].

Наступна ознака - сакральність. У зв'язку з Богом кобзарі бачили своє призначення. Важливо наголосити на тому, що жебраки, сліпців називали старця́ми (у значенні 'бідний'), а кобзарів - ста́рцями (у значенні 'старий мудрець, дід - язичницьке божество, першопредок, волхв'). Про це пише Л. Мусіхіна: Вони - ста́рuуi, які мають добрим людям про Царство Боже і співати-розповідати добрим людям про Царство Боже $i$ царство земне, про сотвореніє світа, про землю, як вона плачеться-

\footnotetext{
* Визвілка - обряд, яким закінчувалося навчання на кобзаря.

*** Традиційно усі гроші, харчі, все, що давали люди, зберігалося в кобзаря.
} 
ридається, бо не може витримати гріхів людських, про дітей Божих, які забули, хто вони такі... I скрізь, де б вони не були, варто було дідові Мартинові витягти з торби кобзу, до них підходили $i$ підходили. Обступали й уважно слухали. Часто дід розповідав, як треба жити по правді та про щуо думати, як боронити свій край від зайд і шанувати свойх героїв. Він учив жити й умирати [6, с. 34]. Фактично кобзар виступав у ролі панотця, який наставляє на шлях Божий свою паству.

Про це також ідеться в романі: Дід тоді був поважнішим за сільського попа, та щзо там попа, - за самого архієрея [6, с. 35]. А коли сліпець співав, він «видавався тоді Устимкові непростою людиною, а якимось могутнім чарівником-відьмаком, щзо може змусити людей відчувати, як він сам, радіти його радощуами, плакати над його жсалощчами. Більше того, йому здавалося, щуо $і$ зілля, й дерева, $і$ корови $з$ вівияли, і навіть річка, та й сама земля уважно прислухається до голосів кобзи й діда, а може, навіть підспівують їм, $i$ щуось неземне, щзось потойбічне, щуось велике, величне і прекрасне народжувалося тоді в світі.

Щось подібне до того, щзо колись покликало його в дорогу. А може изе воно й було?» [6, с. 36].

Такий вплив музики на Устимку не випадковий. Ми вже зазначали, що хлопчик бачить серцем, відчуває значно більше за інших людей (що й дало йому можливість почути Джуму, відчувати підтримку і присутність Господа та ангелів у критичних ситуаціях життя). Цей маленький хлопчик чув Небесну Музику - «світ наповнився ним, його диханням і душею. Устимко зрозумів, що все навколо живе у ритмі його серця, сповнюється ним, а сам він у собі відчув цілий світ» [6, с. 46]. Можемо стверджувати, що дитина почула ту Музику, якою наповнений Всесвіт і почути яку може тільки високодуховна чуттєва особистість або людина, душа якою відлітає в потойбіччя.

У наступному контексті роману змальовано ще одну ознаку кобзарів - силу їхньої молитви: Вечоріло. Вони ніяк не могли знайти пристановищуа на ніч. Було ніби ци не холодно, але дід чогось вперто не хотів ночувати під відкритим небом, казав, щуо сьогодні мусять вони йти людей ... Він ходив від хати до хати, ніби шукав щзось чи когось.

Він майже зовсім проминув невелике село в одну вулицюю, коли дід зупинився. Постояв, здавалося, втягнув носом повітря, немов намагався вловити якийсь запах. Тоді ще раз ... Раптом обернувся $і$ пішов у двір, шуо його вже був проминув [6, с. 61]. Після запросин до столу господар сказав, що співати дід має йти до сусідів, бо в нього жінка народжує. Дивує відповідь сліпого: У вас не співати треба, а молитися [6, с. 62], а через деякий час, після довгих і глибоких молитов, Мартин сказав тихенько поводирю Устимкові: Спи, малий, спи ... а я піду дві душечки рятувати, бо ж до Бога підуть ... рано щуе ӥм. Ой, рано ... [6, с. 62]. Свою поведінку 
кобзар пояснив на наступний день: Бо на тій хаті сидів ангел смерті, $i$ все намагався до хати залетіти, і радів, щуо аж дві душі відразу вихопить. $A$ на порозі сидів інший ангел $і$ плакав, бо не знав чим лиху зарадити [6, c. 68]. Звернемо увагу на той факт, що бачив їх тільки сліпий чоловік, бо «коли очі сония не бачать, то цуе щуе зовсім не означає, щэо й серцฺе незряче» [6, с. 68].

Українці - народ сердечний, саме на наших землях сформувалася філософія серця - кордоцентизм. Тому «зрячим серцем» володів i Устимко. Коли дід ходив шукати розрив-зілля, хлопчик поринав у глибоку молитву, потребу та необхідність у якій відчув усім серцем. Під час такого звертання-молитви людина входила у стан, названий сучасними вченими станом зміненої свідомості: у промовця уповільнюється ритм серцебиття та біотоків мозку, що відповідає стану так званого «повільного сну» (у свідомості такий стан буває тільки в немовлят до двох місяців), тобто свідомість опинялася поза мозком, а вібрації, що їх випромінював співець, входили в суголос з ритмом і вібраціями Всесвіту. Зрозумілими стають слова Христа: «Будьте як діти і спасетеся...» [7, с. 107].

Ось як про це пише авторка: Відкинув ряднину, помаленьку відчинив двері. Так, аби не скрипнули ... перейшов сіни, нишком зайшов до хати. ... Діти спали не всі. Та дівчинка, щуо ввечері зголосилася нагодувати брата, склавши руки, стояла на колінах перед образом $i$ шзось шепотіла. Молилася. По щуоках текли сльози. На вигляд вона була Устимковою ровесницею. Так жаль хлопчикові стало изіє̈ молитвенищуі, щзо й сам незчувся, як опинився поруч із нею і собі тихенько зашепотів "Отче наш». Він розумів, щзо молитися зараз треба за ту жінку, щзо плаче і кричить, за цъю дівчинку, яка, стоячи голими коліньми на твердій $і$ холодній долівці, так ревно просить Бога за матір...

Двоє дітей стояли перед образом на колінах. Дві чисті душі стояли перед самим Богом і просили за третю. I четверту. ...

... А ще злипаються очі і так страшно болять коліна, задерев'яніла спина, але йому здається, щуо як тільки він встане чи засне, тієї ж миті та незнайома жінка за жердкою помре ... і він стояв, шепотів слова молитов, які тільки знав, а може, цуе були й не молитви, бо він ужсе просив допомоги у всіх сил: у сонияя і місяця, у вітру й дошу $i$, навіть, здається, $y$ давно спочилих своїх пращурів. От би тільки вона не помирала ... тільки б не помирала ... Просто треба молитись...» [6, с. 66]. Тільки після появи діда Мартина, хлопчик зрозумів «щуо Бог почув їхні молитви. Все тепер буде добре ... Він похилився $i$ впав на землю. Біля нього звалилися його посестра в молитві. А потім хтось узяв їх на руки і переніс на піл, укрив теплою ковдрою...

Спали, обійнявшись, солодко $і$ довго, як після важкої роботи, $і$ ніхто не наважувався їх будити ... [6, с. 66-67]. 
Крім «зрячого серця», Устимко відчував магію дороги, цього сакрального локусу, який захоплював і керував життям сліпих співаків.

У слов'янській концептуальній і вербальній картинах світу поняття «шляху» й «дороги» посідають дуже важливе місце. Концепт дороги присутній на різних рівнях культури (традиційно-народному та інтелектуально-елітарному), в обрядах і ритуалах, фольклорі, церковній книжності, художніх поетичних і прозаїчних творах, живописі, музиці тощо. Уся сукупність понять, образів, символів, пов'язаних з ідеєю шляху, утворює «міфологему шляху», незмінно й відчутно присутню в колективній людській свідомості. На думку Н. Лисюк, «семантика міфологічної путі містить у собі поняття про перехід небезпечної, невпорядкованої, неосвоєної, чужої ділянки простору - вихідного хаосу, а не космосу» [4, с. 166].

Дорога в українців співвідноситься з життєвим шляхом, шляхом душі в потойбічний світ та семантично виокремлена в перехідних ритуалах. Дорога - це місце, де виявляється доля, удача людини при її зустрічах 3 людьми, тваринами й демонами.

Для кобзарів та їхніх поводирів дорога від села до села дорівнювалася до дороги до Бога, шляхом до духовної, моральної довершеності. Вона поєднувала світські місця (міста, села) зі святими - церквами i монастирями, тобто була єднальною ланкою між повсякденним i духовним, профанним i сакральним. Не забуваймо, що у світогляді українців простір поділявся на «світ своїх/живих» і «світ чужих/мертвих». До «світу своїх» належала територія житла, обійстя, села/міста, до «світу чужих» - усе, що знаходиться поза межею житла, обійстя, села/міста дорога, ліс, озеро тощо. Тому такого містичного значення набувала дорога. Для кобзаря ідеальною була смерть у дорогі: щоб його поховали біля дороги, поставили хрест, щоб повз нього ходили люди.

Устимко відчував магію дороги 3 дитинства. 3 відчуття хлопчиком дороги розпочинається роман: Мандрувати такою дорогою було радісно $i$ приємно, бо ноги провалювалися у товстий шар пилу. Такого щастя не знає ніхто, крім тих, кому доводиться багато подорожувати босоніж. Навіть той, хто взутий у черевики чи навіть чоботи, зняв би їх зараз, аби тільки відчути підошвами иңю ... дорогу ...

... Він виходив на шлях за селом, $i$ оте ЩОСЬ тягнуло його КУДИСЬ...

Але він ішов. Лишав усе, брав у торбу лише кобзу, не набагато меншу за себе $і$ йшов. Хтось чекав на нього на другому кіниі дороги. Хтось або щзось [6, с. 9].

Одного разу хлопчик, граючись 3 іншими, відчув поклик ДОРОГИ. Цей день повністю змінив його життя: I тут він почув, як хтось покликав. Голос той був скрізь: він звучав $і$ в його голові, $і$ в його сериі, $i$, хлопецьь міг 
заприсягтися, аж лящзав понад лугом. Корови перестали пастися $i$ попіднімали голови до неба. $A$ ось із пастушків ніхто нічого не почув. Щось у його грудях відгукнулося на той поклик, ніби якась невидима нитка тієї ж миті зв'язала його з таємничим і невідомим ЧИМОСБ на тому, іншому кінці.

I він пімов.

Щось усередині боліло і непокоӥлось, клубком підступало до горла й тягло кудись у невідомість. Товариші, щзо пасли з ним худобу, спочатку не звернули уваги на те, як він відкинув батіжок і пішов геть.

Kydu?

Haвiuso?

Не знач сам. Не думав ні про матір, ні про себе, ні про кого - таким сильним був той поклик. Коли вже вийиов на дорогу, зрозумів, щуо це вона його кликала, це вона була тією невидимою ниткою між ним $i$ ЧИМОСБ ...

... Він би йшов і йшов далі, але згадалась мама. Зупинився. Задумався. Стояв, ніби між двома «треба» чи двома «хочу», а може, навіть «муиу». Повернуся і пімов назад до свого села ... [6, с. 26-27].

У романі Л. Мусіхіної дорога постає «розмотаним сувоєм полотна», що «стелиться під ноги», а ще герої дорогу міряють казкою: цуе була їхня власна міра відстані. Такої міри відстані не було більше ні в кого. Вони йшли собі дорогою і розповідали казки, часом ті, які чули від людей, $а$ часом придумували свої [6, с. 55].

Дорога в романі постає сакральним простором, де може статися щось надзвичайне, надприродне. Можливо, саме тому в дорозі Мартин уперше продемонстрував свої чаклунські здібності Устимкові: Буря лютувала вже зовсім-зовсім близько.

Торохнув грім.

Блискавиці раз у раз різали небо на иматки. У $\ddot{~ х х ~ с в і т л і ~ д і д о в е ~}$ обличчя ставало синім $і$ страшним. Білі плями очей горіли якимось нетутешнім вогнем. Удень дід був подібний до Бога на образах чи, скоріше, на святого Миколая, а зараз, уночі, більше скидався на мерия, упиря чи навіть самого дідька.

$<\ldots>$

Хлопчик бачить, щуо дід щзось говорить, та хоча стояв зовсім близько біля нього, нічого не чув, бо вітер зривав слова просто з уст $i$ ніс, як осіннє листя, кудись далеко-далеко...

- ... вернись! Відвернись, кажу тобі! - кричав дід. - Ти ... о, .. оглух? Закрий очі й вуха!..

... Дід тим часом скинув торби з плечей, обережно поклав на них мішок з кобзою, вийняв із вузлика у кишені якийсь порошок, посипав ним навколо себе, а тоді взяв обома руками бікоту і підніс ї̈ до неба. Він тряс 
нею, щзось наспівно примовляв, комусь погрожував. Показував якісь знаки на ній. Потім знову тряс $і$ знову щуось примовляв ... Здавалося, він вив разом із вітром чи изе вітер співав разом із ним ...

... Устимко розплющчив очі.

Було вже світло.

Була дорога. I cmen.

Поруч лежав дід. Видно, як упав, так і не вставав. Шапка злетіла $з$ його голови, в руцуі він міцуно тримав бікоту. Трохи далі на торбах спочивала кобза [6, с. 54].

Стан діда Мартина після протистояння бурі нагадує стан Устимки та дівчини після тривалої і глибокої молитви за породіллю і немовля - це духовне і фізичне знесилення, спустошення, що спричинене катарсисом $\mathrm{i}$ яке сприяє переродженню/відродженню душі.

Ще раз чаклунство діда проявилося знову ж таки в дорозі, коли сліпий шукав ліки від хвороби, яку сам же наслав, як покарання, на поводиря свого друга-кобзаря Сашка: Дід стояв нерухомо і щзось шепотів. Амфібрахій не почув ні слова.

Старий на якусь мить завмер, а тоді вдарив бікотою об землю.

Амфібрахій міг присягтися, щзо бачив, як відразу, щзойно дід підняв бікоту, з-під неї забило джерело. Просто так, із каменя. Там, на камені, до изього навіть щзілини не було [6, с. 190].

Та чи не найдивовижнішим було протистояння старця і чуми (смерті). Сталося це знову ж таки в дорозі. Пошесть, мор, страшна хвороба, яка вразила людей, змусила мандрівників повертати додому: Вони все таки повернули назад. Дорогою заходили ще у якісь села. Дід співав. Але він усе прислухався, ніби чекав на когось чи на щуось. Хлопець боявся навіть запитати діда про те, щуо коїться у світі. Здавалося, саме повітря стало густим, як вівсяний кисіль, $і$ люди, тварини й дерева ніби потопали в ньому [6, с. 73]. Авторка описує відчуття хлопчика. Ця зустріч зі смертю переконала сліпого Мартина в тому, що хлопчик надзвичайний - йому дано зір, який зазвичай є тільки у сліпців, відчуття музики, хист до співу: Устимко відчував присутність людей, якимось чином відчував їхній страх (мабуть, саме там відчувають чужсии страх тварини). Йому здавалося, щзо зараз він, зрячий, більше бачить $і$ чує серцеем, шкірою, носом, ніж очима. Очі стали мовби сліпими, і зовсім не мало значення, дивиться він ними чи ні. Щось знову кликало його, $і$ гарячим згустком відгукувався у ньому страх. Зараз він почав розуміти, як відчуває світ дід Мартин і вся ияя його сліпа братія. Цей їхній світ ... він інакиий. Але він існує насправді $[6$, c. 77].

Страх став своєрідним ключем, що відчинив перед хлопчиком двері у світ сліпих. 
Те, що описано в романі далі, повністю суголосно народному світогляду, основам народної магії, яка дійшла до нас бодай в окремих частинах у народних календарних обрядах.

Як відомо, українці з надзвичайною обережністю ставилися до часу, який поділяли на сакральний і профанний. Профанний - буденний - час був сповнений побутовими справами, діями, почуттями. Сакральний час був наповнений священними діями, які брали свій початок у міфічних часах існування людства, був наповнений ритуальними діями, спрямованими на те, щоб у межові періоди людського життя врятувати світ, землю, людство. Тому особливого значення набував Новий рік, коли відбувалося ритуальне відмирання Світу, панування певний час Хаосу, а згодом тріумфальне повернення-відродження Космосу. «Беручи символічну участь у зруйнуванні і новому творенні Світу, людина й сама відроджувалася; вона народжувалася знову, бо починалося нове буття. Кожного Нового року людина почувалася вільнішою і чистішою, бо позбувалася тягаря гріхів та помилок. Вона знову опинялася в казковому часі творення, а отже, часі священному і могутньому, бо цей час належав винятково найвеличнішому акту творення, створенню Всесвіту. Людина символічно знову ставала сучасником космогонії, була присутньому при створенні Світу» [3, с. 37]. Новий рік позначався також ритуальними безчинствами молоді (бешкети на Андрія, водіння Кози, Маланки, колядування і щедрування), коли не можна було робити зауваження або карати за вчинені збитки парубків, особливо на Андрія та колядку, бо «це парубочий день. Хлопці сьогодні при праві» [2].

Так і Мартин: щоб змінити хід подій та врятувати людей від смерті«джуми», влітку, «саме у Петрівку», почав співати колядки, а люди, заряджені енергією кобзарського співу, почали розігрувати водіння Кози, прагнучи таким чином заплутати смерть.

I тут вкотре Устимко продемонстрував свої надзвичайні здібності. 3 усіх присутніх у хаті, де співав Мартин, тільки хлопчик почув, як під’їхала страшна «джума». Він почув стукіт коліс, «як десь на вулищі, саме навпроти хати, зупинилась чи то карета, чи то бричка. Заіржали коні. Було чути, яку хтось так важко зіскочив із неї, щуо аж земля задвигтіла. Той «хтось» підійшов до хати. ...

Жіночий голос покликав знадвору:

- Хто тут? Чи можна зайти?

Видно, та, щзо запитувала, з якоїсь причини не могла зайти до хати без запрошення. ...

- Чи можна зайти до хати?

Їй ніхто не відповів. Вона теж мовчала. Прислухалася. Але люди співали. Весело виводили вже навіть про козу, щуо впала та й нежива стала.... 
Та, щзо стояла під вікном, чи то позіхнула, чи то зітхнула і сказала вже до себе:

- Щось я забарилася ... Уже, видать, і Василя ... Он і козу водять. От час біжить! Ніби ж тільки Трійия була?..

- Устимко чув, як віддаляються від вікна кроки, потім коні від'їздили геть» $[6$, с. 81$]$.

I знову настає катарсис, який письменниця описує коротко, але так схоже з уже пережитим катарсисом діда Мартина та Устимки: Виснажені несподіваними веселощами, люди поснули, хто де був ... [6, с. 81].

Дід із хлопчиком далі вирушили в дорогу, співаючи в селах колядки. Кобзар переміг смерть: Дорогою дід грав колядки, і далеко не всі розуміли, чому він, починаючи псальмами, закінчує колядками. Хтось дивувався, хтось відверто казав, щуо, видно, дід збожеволів, де ж то таке чути, аби у Петрівку співати колядок? Але дід співав ... I не раз Устимко чув, як під вікном знову зупинялася карета, як Джума запитувала, чи є хто в хаті, дивувалася, щзо таки чогось вона не розуміє, бо ж ніби $і$ не Різдво? Нарікала на те, щзо вона вже стара і немічна, сердилася, щзо люди ї дурять ... Казала навіть, щуо була б ї̈ воля - ох би вона иььому сліпому задала! Сама б кобзу побила. Але Устимко вже добре знав, щэо він, чуючи $і$ знаючи, мусить просто мовчати.

I тому він лите голосніше підспівував за дідом ...

I глушили вони своїм співом нарікання й бідкання Джуми, $i$ вона, часом роздратована, а часом сумна $i$, здається, навіть заплакана, безсило відступала.

Хай усі мали їх за трохи божевільних, обоє стариів розуміли, щэо роблять велику справу, рятуючи життя людей, наводячи лад у світі ... [6, c. 84-85].

Останні дві ознаки - бідність і мобільність - пов'язані між собою. Вони спричинені покликанням кобзарів - нести слово Боже людям, а в дорогу зайвого брати не потрібно: сліпа мандрована братія майже ніколи не тягала за собою багато, бо і йти важко, та й не потрібно воно - бо ж у кожнім селі святою справою вважали їх на ніч прийняти й нагодувати. Але, звичайно, про всяк випадок несли вони з собою і борошения трохи чи, там, пшона, сала, цибулі. Та ще давали їм з собою на дорогу часом $i$ пирогів, і хліба, і яєиь, і там чого Бог послав [6, с. 169].

Насамкінець акцентуємо увагу на змінах, які відбуваються у тлумаченні образу Мартина - від сліпого діда до чаклуна, який зупиняє бурю, перемагає смерть, і врешті-решт до самого Бога. Останній образ є фінальним у книзі. Він постає у сцені смерті вже старого Устима, колишнього хлопчика поводиря: Старець напівлежав, опершись на дерево. ... Серие билось усе рідше $і$ рідще. Стрепенулось востаннє $i$... зупинилось. 
Хтось торкнув його за плече. «Ти хто?» - «Я? Я - Бог. Забув мене?» - «Забув... Я що, помер?»- «Помер». - «А Смерть де?»- «Смерть?»Бог засміявся. - Ти прожив таке довге життя і досі віриш у ті казки? Немає ніякої Смерті! - «Ну щэо, пішли?» - «Я?» - «Ти, ти ... Яблуко будеш?» ${ }^{* * *}$

I Бог простягнув йому велике яблуко, в якому просвічувались $i$ торохтіли зернята.

Устим удивлявся в обличчя Бога. Він був дуже схожий на діда Мартина, сліпого кобзаря, якого він знав у дитинстві.

Тільки тепер Бог був зрячим [6, с. 249].

Усе відбувалося так, як розповідав Устимкові ще на початку роману Мартин: ... і коли чоловік праведен помирає, то відмикає він [Петро] перед ним браму, і тоді сидять на деревах янголи і архангели, у кожного з них у руках ліра, бубен, скрипка чи коза, і грають вони тільки для того, хто до Раю входить, і кращої музики немає ніде в світі. I від тих чарівних звуків у безногих виростають ноги, у безруких - руки, глухі починають чути, а темні - прозрівають ... I сліпі музики, ті, щзо вірно служили людям та Богові, самі стають отими янголами. I до кінця віку музикують вони у Раю і грою своєю зиіляють, повертають до вічного життя... Хоча $і$ на цьому світі силу немалу вони мають, бо ж душі зиілюють ... [6, с. 128].

Що ж до образу Мартина, вважаємо, що читач сам для себе має вирішити: ким був Мартин, як пожив своє життя Устимко, який шлях обрати в житті для самого себе. Такі книги, як роман «Звичайник» Лілії Мусіхіної, покликані пробудити в читачів, у молодого покоління роздуми над вічними питаннями, що століттями постають перед людьми і чіткої відповіді на які не існує: «Хто я?», «Для чого я прийшов у цей світ?», «Як я маю прожити своє земне життя?», «А що там, за межею життя $\mathrm{i}$ смерті?». Відповідей немає. Кожен вирішує сам.

\section{СПИСОК ВИКОРИСТАНОЇ ЛІТЕРАТУРИ}

1. Бюрклен, К. Психология слепых / К. Бюрклен ; под ред. и с предисл. В. А. Гандера. - М. : Гос. уч.-пед. изд-во, 1934. - 264 с.

2. Воропай, О. Звичаї нашого народу: Етнограф. нарис / Олекса Воропай ; худ.-оформлювач Л. Д. Киркач-Осипова. - Харків : Фоліо, 2005. - 508 с.

3. Еліаде, М. Священне і мирське / Мирча Еліаде. - К. : Вид-во Соломії Павличко «ОСНОВИ», 2001. - 116 с.

4. Лисюк, Н. А. Міфологічний хронотоп : матеріали до курсів «Міфологія», «Міфологія слов' янська і світова» / Н. А. Лисюк. - К., 2006. - 198 с.

5. Михайлова, К. О семантике странствующего певца-нищего в славянской культуре / К. Михайлова // Язык культуры: семантика и грамматика. - М., 2004. - C. $138-156$. 
6. Мусіхіна, Л. Звичайник : роман / Лілія Мусіхіна. - К. : Дуліби, 2014. - 252 с.

7. Тихоплав, В. Ю. Кардинальный поворот / В. Ю. Тихоплав, Т. С. Тихоплав. СПб. : ИД «ВЕСЬ», 2004. - 320 с.

Стаття надійшла 08.04.2016 року

УДК 821.161.2+39(477)

Вікторія Кириченко

(Умань, Україна)

\section{ТРАДИЦІЙНЕ ДОЗВІЛЛЯ УКРАЇНСЬКОЇ МОЛОДІ У ТВОРАХ ГР. КВІТКИ-ОСНОВ'ЯНЕНКА}

У статті проаналізовано твори Гр. Квітки-Основ'яненка та виявлено й охарактеризовано основні форми дозвілля молоді, щзо побутували у XVIII - XIX ст. $в$ Україні.

Ключові слова: дозвілля, молодь, вечорниці, танці, колядки, Купала, музики.

Кириченко В. Традиционный досуг украинской молодежи в произведениях Гр. Квитки-Основьяненко.

В статье изучены произведения Гр. Квитки-Основьяненко, в них выявлень и охарактеризованы основные формы досуга молодежи, которые были распространены XVIII - XIX вв. в Украине.

Ключевые слова: досуг, молодежь, вечерницы, танць, колядки, Купала, музыка.

Kyrychenko $\boldsymbol{V}$. Traditional Ukrainian youth entertainment in Hr. KvitkaOsnov'ianenko works.

The author of the article analyzed the works of Hr. Kvitka-Osnov'ianenko. The main forms of leisure of youth were identified and characterized. All that existed in Ukrainian the $18^{\text {th }}-19^{\text {th }} \mathrm{cc}$. In the stories of the author were demonstrated the attitude of our ancestors to some entertainment as well as the requirements and prohibitions concerning behavior and punishment for their violation or default.

Keywords: leisure, youth, dances, Carols, Kupala, musicians.

Гр. Квітку-Основ’яненка вважають засновником художньої прози і жанру соціально-побутової комедії в класичній українській літературі. Його творчість не тільки значно вплинула на розвиток вітчизняної літератури, але й дала можливість нашим сучасникам ознайомитися 3 життям українців XVIII - XIX ст., з їхнім побутом і традиціями. Можемо стверджувати, що твори Гр. Квітки-Основ'яненка - це своєрідний посібник з українознавства.

Аналіз творів Гр. Квітки-Основ'яненка дозволив нам виокремити у їх змісті такі форми дозвілля: вечорниці, вулиця, танці, календарні свята (клечальна неділя, Петра, Семена, Пилипа, «Ганнинозачатіє», Великдень 